\title{
High Variability of the Definition of Recurrent Glenohumeral Instability: An Analysis of the Current Literature by a Systematic Review
}

\author{
Hassanin Alkaduhimi, M.D., James W. Connelly, B.A., Derek F. P. van Deurzen, M.D., \\ Denise Eygendaal, M.D., Ph.D., and Michel P. J. van den Bekerom, M.D., Ph.D.
}

\begin{abstract}
Purpose: To determine the definitions for recurrence used in the literature, assess the consensus in using these definitions, and determine the impact of these definitions on recurrence rates. Methods: A literature search was performed in PubMed and EMBASE including studies from 2000 to 2020 reporting on recurrence rates after anterior arthroscopic shoulder instability surgery. Dislocation, apprehension, subluxation and recurrence rates were compared. Results: Ninety-one studies were included. In $68 \%$ of the eligible studies, recurrence rates are not well defined. Thirty (33\%) studies did not report on dislocations, 45 (49\%) did not report on subluxations, and 58 (64\%) did not report on apprehension. Seventeen different definitions for recurrence of instability, 4 definitions of dislocations, and 8 definitions of subluxation were used. Conclusion: Recurrence rates are poorly specified and likely underreported in the literature, hampering comparison with results of other studies. This highlights the need for a consensus on definition of recurrence across shoulder instability studies. We recommend not using the definition recurrence of instability anymore. We endorse defining dislocations as a radiographically confirmed dislocation or a dislocation that is manually reduced, subluxations as the feeling of a dislocation that can be (spontaneously) reduced without the need for a radiographically confirmed dislocation, and a positive apprehension sign as fear of imminent dislocation when placing the arm in abduction and external rotation during physical examination. Reporting on the events resulting in a dislocation or subluxation aids in making an estimation of the severity of instability. Level of Evidence: Level IV, systematic review.
\end{abstract}

D epending on the risks for recurrent shoulder instability can be managed conservatively, with (arthroscopic) soft-tissue procedure, or (open) bony procedures. ${ }^{1}$ The arthroscopic Bankart repair is the most used procedure, including up to $87 \%$ of instability procedures. ${ }^{2}$ Several studies have assessed recurrence

From the Shoulder and Elbow Unit, Joint Research (J.A., D.F.P.vD., M.P.J.vdB.), Amsterdam, the Netherlands; Department of Orthopaedic Surgery, Massachusetts General Hospital (J.W.C.), Boston, Massachusetts, U.S.A.; the Orthopaedic Department, Amphia Ziekenhuis (D.E.), Breda, the Netherlands; and the Amsterdam University Medical Centres (D.E., M.P.J.vdB.), Amsterdam, the Netherlands.

The authors report that they have no conflicts of interest in the authorship and publication of this article. Full ICMJE author disclosure forms are available for this article online, as supplementary material.

Received September 7, 2020; accepted February 11, 2021.

Address correspondence to Hassanin Alkaduhimi, M.D., Address: Oosterpark 9, 1091 AC Amsterdam, the Netherlands. E-mail: hassaninalkaduhimi@gmail.com.

(C) 2021 THE AUTHORS. Published by Elsevier Inc. on behalf of the Arthroscopy Association of North America. This is an open access article under the CC BY license (http://creativecommons.org/licenses/by/4.0/).

2666-061X/201519

https://doi.org/10.1016/j.asmr.2021.02.002 rates after shoulder instability surgery. The recurrence rate for the general population varies from $0 \%$ to $8 \%$ after Latarjet procedure ${ }^{3}$ to $3.4 \%$ to $35 \%$ after arthroscopic Bankart repair. ${ }^{4,5}$ Although most studies describe rates of recurrent dislocation (instability), there is no consensus on the definition of these terms. For example, Randelli et al. ${ }^{5}$ uses redislocation or subluxation as a definition of recurrent instability, whereas Gerometta et al $^{4}$ does not describe a definition of a recurrence of instability/dislocation. As a result, findings in previous studies were hard to compare. ${ }^{6} \mathrm{Kuhn}^{7}$ has described that shoulder instability studies are procedure based and not condition based, resulting in unclear definitions of instability. He introduced the frequency, etiology, direction, and severity system for describing instability. Kennedy et al. ${ }^{8}$ has described that there is a wide variety of definitions of recurrence in the literature and that the recurrence rates vary according to level of evidence, age, follow-up time, and attrition rate. Although Kennedy et al. ${ }^{8}$ have noticed that there are many different definitions used in the literature, it is still unclear how many studies did not define these definitions. The purposes of our study were to 
determine the definitions for recurrence used in the literature, assess the consensus in using these definitions, and determine the impact of these definitions on recurrence rates. We hypothesized that for shoulder instability the definition of recurrence is poorly reported and that there is no consensus on the definition to be used.

\section{Methods}

This is a systematic review of available literature on the definition of recurrent anterior shoulder instability and is performed according to the Preferred Reporting Items for Systematic Reviews and Meta-Analyses
(PRISMA) guideline. ${ }^{9}$ No review protocol was identified for this study.

\section{Literature Search and Study Selection}

A literature search was performed on August 5, 2020, in PubMed and EMBASE with predefined search terms (Appendix 1), including all studies mentioning recurrence rates in Dutch, German, Arabic, and English. The search was limited to studies between 2000 and 2020 to give insight into definition of recurrence in the most recent literature. The inclusion criteria included studies assessing recurrence rates after arthroscopic anterior shoulder instability surgery. Letters to the editors, instructional courses, animal/cadaver/in vitro studies,

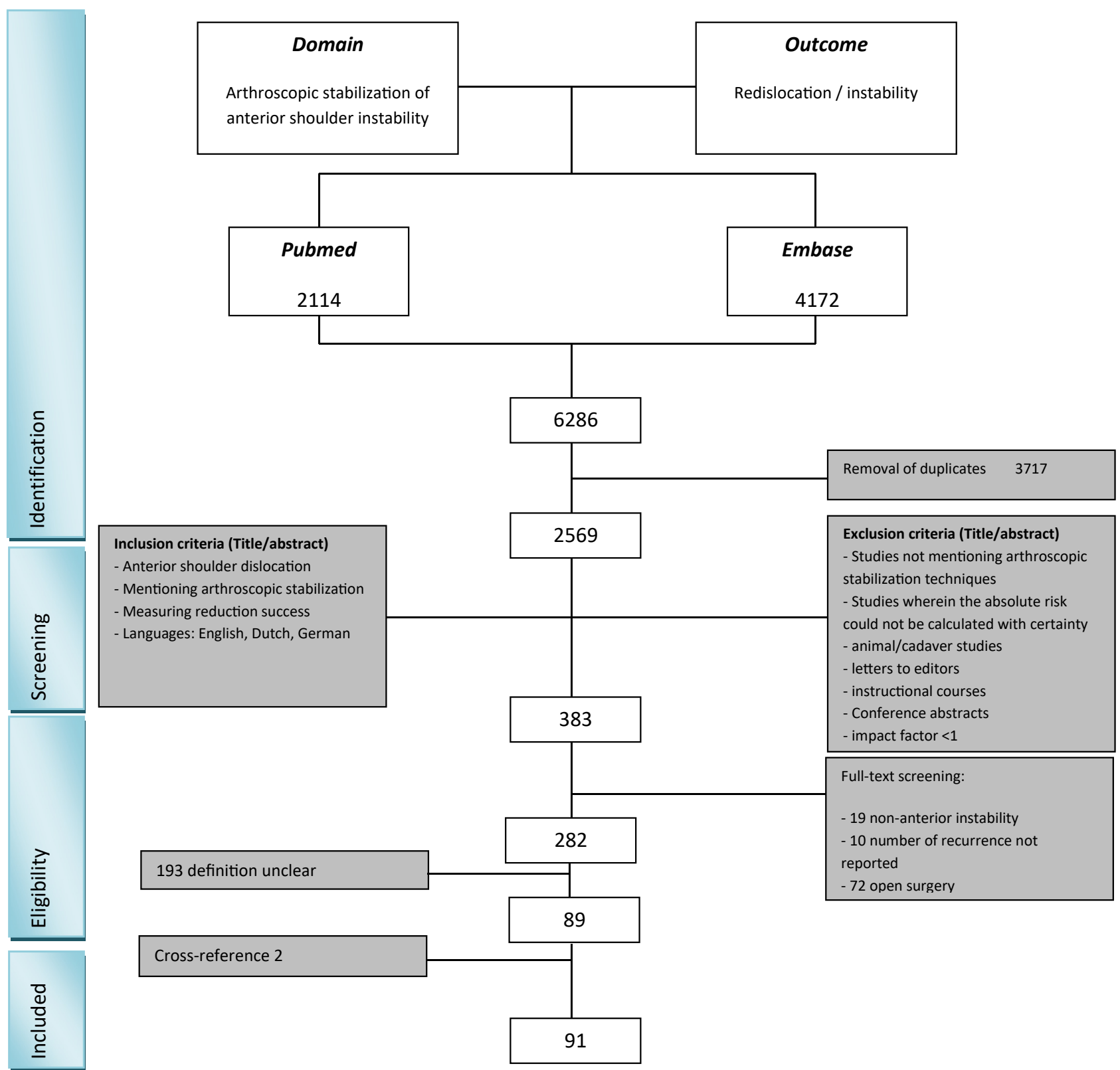

Fig 1. Flow chart. From 2569 studies in PubMed and EMBASE 282 are full-text screened, from which 89 studies are included. 


\begin{tabular}{|c|c|c|c|c|c|c|c|c|c|c|c|}
\hline \multirow[b]{2}{*}{ Article (reference) } & \multirow[b]{2}{*}{$\begin{array}{l}\text { Number of } \\
\text { Patients (n) }\end{array}$} & \multicolumn{6}{|c|}{ Part a } & \multicolumn{3}{|c|}{ Part B } & \multirow{2}{*}{$\begin{array}{c}\text { Mean } \\
\text { Modified } \\
\text { Coleman } \\
\text { Score }\end{array}$} \\
\hline & & $\begin{array}{c}\text { Mean } \\
\text { Follow-up }\end{array}$ & Open/Arthroscopic & $\begin{array}{l}\text { Diagnostic } \\
\text { Certainty }\end{array}$ & Type of Study & $\begin{array}{l}\text { Description of } \\
\text { Treatments }\end{array}$ & $\begin{array}{l}\text { Postoperative } \\
\text { Rehabilitation }\end{array}$ & $\begin{array}{l}\text { Outcome } \\
\text { Criteria }\end{array}$ & $\begin{array}{l}\text { Procedure for } \\
\text { Assessing } \\
\text { Outcomes }\end{array}$ & $\begin{array}{l}\text { Description } \\
\text { of Subjects }\end{array}$ & \\
\hline Thal et al. ${ }^{12}$ & 72 & 24 & + & + & Retrospective & + & + & 1,3 & $2,3,4$ & 1,2 & 69 \\
\hline Law et al. ${ }^{13}$ & 38 & 28 & + & + & Retrospective & + & + & 1,3 & 3,4 & 1,2 & 59 \\
\hline Wolf et al. ${ }^{53}$ & 45 & 58 & + & + & Retrospective & + & + & $1,2,3$ & 3,4 & 1 & 62 \\
\hline Park et al. ${ }^{46}$ & 20 & 29 & + & + & Retrospective & + & + & $1,2,3$ & 3,4 & 1,2 & 61 \\
\hline Cho et al. ${ }^{55}$ & 72 & 25 & + & + & Retrospective & + & + & $1,2,3$ & 3,4 & 1,2 & 69 \\
\hline Porcellini et al. ${ }^{24}$ & 385 & 36 & + & + & Retrospective & + & + & $1,2,3$ & - & 1,2 & 61 \\
\hline Hantes et al. $^{93}$ & 63 & 39 & + & + & Prospective & + & + & $1,2,3$ & $1,2,3,4$ & 1,2 & 94 \\
\hline Lützner et al. $^{35}$ & 39 & 31 & $+1-$ & - & Retrospective & + & + & $1,2,3$ & $1,3,4$ & 1 & 53 \\
\hline Flinkkilä et al. ${ }^{58}$ & 174 & 51 & + & + & Retrospective & + & + & $1,2,3$ & $1,3,4$ & 1,2 & 75 \\
\hline Imhoff et al. ${ }^{69}$ & 190 & 37 & + & + & Retrospective & + & + & $1,2,3,4$ & $1,3,4$ & 1 & 73 \\
\hline Park et al. ${ }^{56}$ & 161 & 37 & + & + & Retrospective & + & + & $1,2,3$ & $2,3,4$ & 1 & 69 \\
\hline Taverna et al. ${ }^{14}$ & 26 & 30 & + & + & Retrospective & + & + & $1,2,3$ & 3,4 & 1 & 56 \\
\hline Kim et al. ${ }^{80}$ & 110 & 45 & + & + & Retrospective & + & + & $1,2,3$ & $1,2,3,4$ & 1,2 & 79 \\
\hline Van der Linde et al. ${ }^{95}$ & 70 & 108 & + & + & Prospective & + & + & $1,2,3,4$ & $1,3,4$ & 1,2 & 96 \\
\hline Gasparini et al. ${ }^{91}$ & 143 & 81 & + & + & Retrospective & + & + & $1,2,3$ & $1,3,4$ & 1 & 73 \\
\hline Kemp et al. ${ }^{87}$ & 40 & 24 & + & - & Prospective & $+1-$ & + & $1,2,3$ & $1,3,4$ & 1,2 & 74 \\
\hline Ahmed et al. ${ }^{88}$ & 302 & 68 & + & + & Retrospective & + & + & $1,2,3,4$ & 3,4 & 1 & 71 \\
\hline Kim et al. ${ }^{52}$ & 34 & 34 & + & + & Retrospective & + & + & $1,2,3$ & 3,4 & 1 & 56 \\
\hline Sommaire et al. ${ }^{86}$ & 77 & 44 & + & + & Retrospective & + & + & $1,2,3$ & 3,4 & 1,2 & 70 \\
\hline Milano et al. ${ }^{94}$ & 70 & 24 & + & + & RCT & + & + & $1,2,3,4$ & $1,2,3,4$ & 1 & 89 \\
\hline Owens et al. ${ }^{57}$ & 39 & 140 & + & - & Prospective & + & + & $1,2,3,4$ & $1,3,4$ & - & 75 \\
\hline Mohtadi et al. ${ }^{89}$ & 54 & 24 & $+1-$ & + & RCT & + & + & $1,2,3$ & $1,2,3,4$ & 1,2 & 82 \\
\hline Shin et al. ${ }^{90}$ & 62 & 47 & + & + & Retrospective & + & + & $1,2,3$ & $1,3,4$ & 1 & 70 \\
\hline Tordjman et al. ${ }^{54}$ & 31 & 61 & + & + & Retrospective & + & + & $1,2,3$ & 3,4 & 1,2 & 67 \\
\hline Robinson et al. ${ }^{92}$ & 84 & 24 & + & + & RCT & + & + & $1,2,3,4$ & $1,2,3,4$ & 1,2 & 94 \\
\hline Lee et al. $^{59}$ & 170 & 38 & + & + & Retrospective & + & + & $1,2,3$ & 3,4 & 1,2 & 70 \\
\hline Torrance et al. ${ }^{15}$ & 67 & 33 & + & + & Retrospective & + & + & $1,2,3$ & - & 1,2 & 61 \\
\hline Vermeulen et al. ${ }^{60}$ & 147 & 76 & + & + & Retrospective & + & + & $1,2,3,4$ & $1,3,4$ & 1 & 76 \\
\hline Chan et al. ${ }^{16}$ & 131 & 24 & + & + & Retrospective & + & + & $1,2,3$ & - & 1,2 & 61 \\
\hline Park et al. ${ }^{61}$ & 193 & 37 & + & + & Retrospective & + & + & $1,2,3$ & 3,4 & 1,2 & 74 \\
\hline Ruiz Ibán et al. ${ }^{17}$ & 140 & 64 & + & + & Retrospective & $+1-$ & - & $1,2,3$ & - & 1 & 52 \\
\hline Su et al. ${ }^{18}$ & 65 & 56 & + & + & Retrospective & + & + & $1,2,3$ & - & 1 & 59 \\
\hline Dickens et al. ${ }^{19}$ & 29 & One season & $+1-$ & - & Prospective & $+1-$ & + & $1,2,3$ & 1 & 1 & 53 \\
\hline Chen et al. ${ }^{20}$ & 221 & 50 & + & + & Retrospective & + & + & $1,2,3$ & 2 & 1 & 69 \\
\hline Moore et al. ${ }^{21}$ & 34 & 52 & + & - & Retrospective & + & + & $1,2,3$ & $2,3,4$ & 1 & 58 \\
\hline Yapp et al. ${ }^{62}$ & 33 & 170 & $+1-$ & - & RCT & + & + & $1,2,3,4$ & $1,2,3,4$ & 1 & 81 \\
\hline Rhee et al. ${ }^{63}$ & 48 & 35 & + & + & Retrospective & + & + & $1,2,3$ & $1,2,3,4$ & 1,2 & 73 \\
\hline Oh et al. ${ }^{64}$ & 120 & 28 & + & + & Retrospective & + & + & $1,2,3$ & $2,3,4$ & 1,2 & 71 \\
\hline Ono et al. ${ }^{65}$ & 51 & 121 & + & + & Retrospective & + & + & $1,2,3$ & $1,3,4$ & 1 & 70 \\
\hline Nakagawa et al. ${ }^{22}$ & 140 & 24 & + & + & Retrospective & + & + & $1,2,3$ & 1 & 1 & 61 \\
\hline Iizawa et al. ${ }^{66}$ & 68 & 31 & + & + & Retrospective & + & + & $1,2,3$ & $1,3,4$ & 1,2 & 72 \\
\hline Lavoué et al. ${ }^{23}$ & 41 & 72 & $+1-$ & + & Retrospective & + & + & $1,2,3$ & $1,3,4$ & 1 & 67 \\
\hline Pandey et al. ${ }^{25}$ & 136 & 49 & $+1-$ & + & Retrospective & + & + & $1,2,3$ & 3,4 & 1 & 62 \\
\hline
\end{tabular}




\begin{tabular}{|c|c|c|c|c|c|c|c|c|c|c|c|}
\hline \multirow[b]{2}{*}{ Article (reference) } & \multirow[b]{2}{*}{$\begin{array}{l}\text { Number of } \\
\text { Patients (n) }\end{array}$} & \multicolumn{6}{|c|}{ Part a } & \multicolumn{3}{|c|}{ Part B } & \multirow{2}{*}{$\begin{array}{c}\text { Mean } \\
\text { Modified } \\
\text { Coleman } \\
\text { Score }\end{array}$} \\
\hline & & $\begin{array}{c}\text { Mean } \\
\text { Follow-up }\end{array}$ & Open/Arthroscopic & $\begin{array}{l}\text { Diagnostic } \\
\text { Certainty }\end{array}$ & Type of Study & $\begin{array}{l}\text { Description of } \\
\text { Treatments }\end{array}$ & $\begin{array}{l}\text { Postoperative } \\
\text { Rehabilitation }\end{array}$ & $\begin{array}{c}\text { Outcome } \\
\text { Criteria }\end{array}$ & $\begin{array}{l}\text { Procedure for } \\
\text { Assessing } \\
\text { Outcomes }\end{array}$ & $\begin{array}{l}\text { Description } \\
\text { of Subjects }\end{array}$ & \\
\hline Brzóska et al. ${ }^{67}$ & 100 & 83 & + & + & Retrospective & + & + & $1,2,3$ & $1,2,3,4$ & 1 & 77 \\
\hline Ernstbrunner et al. ${ }^{26}$ & 36 & 158 & $+1-$ & + & Retrospective & + & + & $1,2,3$ & $1,2,3,4$ & 1 & 68 \\
\hline Gül et al. ${ }^{27}$ & 62 & 29 & + & + & Retrospective & + & + & $1,2,3$ & $1,3,4$ & 1 & 67 \\
\hline Loppini et al. ${ }^{28}$ & 670 & 101 & + & + & Retrospective & + & + & $1,2,3$ & - & 1 & 62 \\
\hline Park et al. ${ }^{29}$ & 195 & 24 & + & + & Retrospective & + & + & $1,2,3$ & $1,3,4$ & 1 & 67 \\
\hline Jeon et al. ${ }^{30}$ & 118 & 28.2 & $+1-$ & + & Retrospective & + & + & $1,2,3$ & 3,4 & 1 & 59 \\
\hline $\mathrm{O}^{\prime}$ Neill et al. ${ }^{11}$ & 20 & 24 & $+1-$ & + & Retrospective & $+1-$ & - & $1,2,3$ & $1,3,4$ & 1 & 48 \\
\hline Zimmermann et al. ${ }^{31}$ & 271 & 120 & $+1-$ & + & Retrospective & + & + & $1,2,3$ & $1,3,4$ & 1 & 70 \\
\hline Flinkkilä et al. ${ }^{32}$ & 167 & 122 & + & + & Retrospective & + & + & $1,2,3$ & $1,2,3,4$ & 1 & 77 \\
\hline McRae et al. ${ }^{96}$ & 74 & 24 & + & + & RCT & + & + & $1,2,3$ & $1,2,3,4$ & 1 & 86 \\
\hline Bessière et al. ${ }^{33}$ & 93 & 72 & $+1-$ & - & Retrospective & $+1-$ & + & $1,2,3$ & $1,2,3,4$ & 1 & 64 \\
\hline Rose et al. ${ }^{68}$ & 65 & 63 & + & + & Retrospective & + & + & $1,2,3$ & $1,3,4$ & 1,2 & 78 \\
\hline Bessière et al. ${ }^{34}$ & 51 & 64 & $+1-$ & - & Retrospective & $+1-$ & - & $1,2,3,4$ & $2,3,4$ & 1,2 & 59 \\
\hline Castagna et al. ${ }^{70}$ & 65 & 63 & + & - & Retrospective & + & + & $1,2,3$ & $1,3,4$ & 1,2 & 73 \\
\hline Thomazeau et al. ${ }^{36}$ & 125 & 18 & + & + & Prospective & $+1-$ & + & $1,2,3$ & $1,3,4$ & 1 & 62 \\
\hline Kim et al. ${ }^{37}$ & 59 & 77 & + & - & Retrospective & + & + & $1,2,3$ & 3,4 & 1,2 & 66 \\
\hline Ozbaydar et al. ${ }^{71}$ & 93 & 47 & + & + & Retrospective & + & + & $1,2,3$ & $1,3,4$ & 1,2 & 75 \\
\hline Boileau et al. ${ }^{72}$ & 91 & 36 & + & + & Retrospective & + & + & $1,2,3$ & $1,2,3,4$ & 1 & 71 \\
\hline Calvo et al. $^{73}$ & 61 & 45 & + & + & Prospective & + & + & $1,2,3$ & $1,2,3,4$ & 1,2 & 79 \\
\hline Kim et al. ${ }^{97}$ & 62 & 31 & + & + & RCT & + & + & $1,2,3$ & $1,2,3,4$ & 1,2 & 91 \\
\hline Kim et al. ${ }^{74}$ & 167 & 44 & + & + & Prospective & + & + & $1,2,3$ & $1,3,4$ & 1,2 & 75 \\
\hline Sperber et al. ${ }^{38}$ & 30 & 24 & $+1-$ & + & RCT & $+1-$ & + & $1,2,3$ & $1,3,4$ & 1 & 68 \\
\hline Nakagawa et al. ${ }^{39}$ & 257 & 24 & + & + & Retrospective & + & + & $1,2,3$ & - & 1 & 56 \\
\hline Nakagawa et al. ${ }^{40}$ & 93 & 24 & + & + & Retrospective & + & + & $1,2,3$ & - & 1,2 & 61 \\
\hline Chechik et al. ${ }^{41}$ & 83 & 46 & + & - & Retrospective & + & + & $1,2,3$ & 3,4 & 1,2 & 65 \\
\hline Cole et al. ${ }^{98}$ & 37 & 36 & $+1-$ & + & RCT & + & + & $1,2,3,4$ & $1,2,3,4$ & 1,2 & 85 \\
\hline Anderl et al. ${ }^{42}$ & 15 & 26 & + & + & Prospective & + & + & $1,2,3$ & $1,3,4$ & 1,2 & 62 \\
\hline Constantinou et al. ${ }^{75}$ & 32 & 217 & + & + & RCT & + & - & $1,2,3$ & $1,2,3,4$ & 1 & 79 \\
\hline De Giorgi et al. ${ }^{43}$ & 22 & 56 & + & + & Retrospective & + & + & $1,2,3$ & $2,3,4$ & 1,2 & 68 \\
\hline Salomonsson et al. ${ }^{99}$ & 62 & 120 & + & - & RCT & $+/-$ & + & $1,2,3$ & $1,2,3,4$ & 1,2 & 87 \\
\hline Garcia et al. ${ }^{44}$ & 24 & 41 & + & + & Retrospective & $+/-$ & + & $1,2,3,4$ & $1,3,4$ & 1,2 & 67 \\
\hline Armangil et al. ${ }^{76}$ & 72 & 49 & + & + & Retrospective & + & + & $1,2,3$ & $1,3,4$ & 1,2 & 75 \\
\hline Boughebri et al. ${ }^{77}$ & 45 & 79 & + & + & Retrospective & + & + & $1,2,3$ & $1,3,4$ & 1 & 70 \\
\hline Kim et al. ${ }^{78}$ & 36 & 42 & + & + & Retrospective & + & + & $1,2,3$ & $1,2,3,4$ & 1,2 & 73 \\
\hline McCabe et al. ${ }^{45}$ & 31 & 41 & + & + & Retrospective & + & + & $1,2,3$ & $1,3,4$ & 1 & 64 \\
\hline Ng and $\mathrm{Kumar}^{79}$ & 87 & 42 & + & + & Prospective & + & + & $1,2,3$ & $1,2,3,4$ & 1,2 & 79 \\
\hline Ee et al. ${ }^{81}$ & 79 & 24 & + & + & Retrospective & + & + & $1,2,3,4$ & $1,3,4$ & 1,2 & 75 \\
\hline Boileau et al. ${ }^{47}$ & 19 & 43 & + & + & Retrospective & + & + & $1,2,3,4$ & $1,2,3,4$ & 1 & 64 \\
\hline Sedeek et al. ${ }^{48}$ & 40 & 30 & + & + & Retrospective & + & + & $1,2,3,4$ & 3,4 & 1,2 & 64 \\
\hline Phadnis et al. ${ }^{49}$ & 141 & 47 & + & + & Case-control & + & + & $1,2,3$ & - & 1,2 & 64 \\
\hline Franceschi et al. ${ }^{50}$ & 50 & 25 & + & + & Retrospective & + & + & $1,2,3$ & $2,3,4$ & 1,2 & 68 \\
\hline Zhu et al. ${ }^{82}$ & 49 & 29 & + & + & Retrospective & + & + & $1,2,3$ & $1,2,3,4$ & 1,2 & 73 \\
\hline Mohtadi et al. ${ }^{83}$ & 83 & 24 & + & - & RCT & + & + & $1,2,3$ & $1,2,3,4$ & 1 & 81 \\
\hline
\end{tabular}




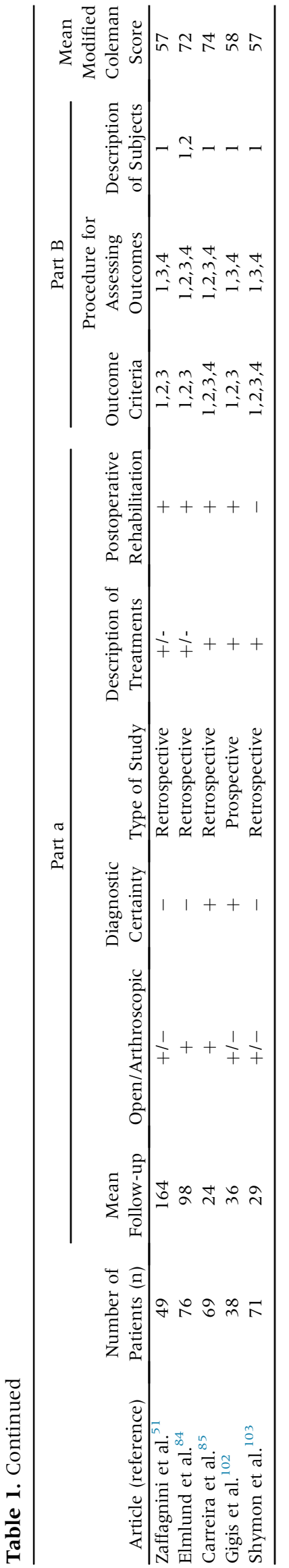

conference papers, and studies published in journals with an impact factor $<1$ at the time of the literature search were excluded. Studies wherein the definition of recurrence was not explicitly defined were excluded. First, the studies were selected on title and abstract using the predetermined inclusion and exclusion criteria by 2 authors (H.A. and J.W.C.) independently. Hereafter full-texts were screened and studies were cross-referenced to search for additional studies. Disagreement was resolved by discussion. Agreement between the 2 observers was assessed using Cohen's kappa, which is a scale of agreement ranging from 0 to 1. A kappa 0.21 to 0.40 corresponds with fair agreement, 0.41 to 0.60 with moderate agreement, 0.61 to 0.80 with substantial agreement, 0.81 to 0.99 with near-perfect agreement, and 1.00 with perfect agreement.

\section{Data Extraction}

First, we checked whether the authors reported on recurrence rates and how they defined recurrence of instability, subluxations, and dislocations. Afterward, the recurrence rates, dislocation rate, subluxation rate, and positive apprehension rate were extracted and presented. The methodological quality of each study was assessed separately by the same 2 authors using the Coleman Methodology Score. ${ }^{10}$ The total number of points correlates with poor (0-49 points), fair (50-69 points), good (70-84 points), or excellent (85-100 points) quality of the study.

\section{Results}

\section{Study Selection}

In total, 2,569 titles and abstracts were screened, from which 383 studies were full-text screened resulting in 89 studies being included in the final analysis (Fig 1). From the 282 studies that were eligible for inclusion, $193(68 \%)$ were excluded because the definition of recurrence was not defined clearly. Cross-referencing resulted in inclusion of 2 additional studies. The 2 observers agreed on $83.7 \%$ of the articles with a Cohen's kappa of 0.67 .

\section{Critical Appraisal and Definition of Recurrence}

On the Coleman methodology score, one scored poor, ${ }^{11} 43$ studies scored fair, ${ }^{12-56} 37$ scored good, ${ }^{57-91}$ and 8 scored excellent ${ }^{92-99}$ (Table 1). From the included studies only 30 studies $(34 \%)$ reported on the definition of a subluxation, and 26 studies (29\%) reported on the definition of a dislocation. In total 17 different definitions for recurrence were used, 8 definitions for subluxations were used, and 4 definitions of a dislocation (Tables 2 and 3). The most frequently used definitions for a recurrence were dislocation or a subluxation (DS) and dislocation, subluxation and/or 
Table 2. Results of the studies

\begin{tabular}{|c|c|c|c|c|c|c|}
\hline Study & $\begin{array}{l}\text { Patients } \\
\text { Undergoing } \\
\text { Arthroscopic } \\
\text { Treatment }\end{array}$ & $\begin{array}{l}\text { Definition of } \\
\text { recurrence }\end{array}$ & $\begin{array}{l}\text { Dislocation } \\
\quad \mathrm{N}(\%)\end{array}$ & $\begin{array}{l}\text { Subluxation } \\
\text { N (\%) }\end{array}$ & $\begin{array}{l}\text { Apprehension } \\
\text { N (\%) }\end{array}$ & $\begin{array}{c}\text { Recurrence of } \\
\text { Instability N (\%) }\end{array}$ \\
\hline Thal et al. ${ }^{12}$ & 72 & DSA & $4(6)$ & $1(1)$ & & $5(7)$ \\
\hline Law et al. ${ }^{13}$ & 38 & DSA & $2(5)$ & & $2(5)$ & $2(5)$ \\
\hline Wolf et al. ${ }^{53}$ & 45 & DSA & $2(4)$ & 0 & $5(11)$ & $7(15.5)$ \\
\hline Park et al. ${ }^{46}$ & 20 & DSA & $2(10)$ & $1(5)$ & & $3(16)$ \\
\hline Cho et al. ${ }^{55}$ & 72 & DSA & $5(7)$ & & $6(8)$ & $11(15)$ \\
\hline Porcellini et al. ${ }^{24}$ & 385 & DS & $31(8)^{*}$ & & & $31(8)^{*}$ \\
\hline Hantes et al. ${ }^{93}$ & 63 & DS & $1(2)$ & $1(2)$ & $5(8)$ & $2(3)$ \\
\hline Lützner et al. ${ }^{35}$ & 39 & DS & $6(15)$ & $3(8)$ & $5(14)$ & $9(23)$ \\
\hline Flinkkilä et al. ${ }^{58}$ & 170 & DS & $15(9)$ & $18(11)$ & & $33(19)$ \\
\hline Imhoff et al. ${ }^{69}$ & 190 & DS & $20(11)$ & $7(4)$ & & $27(14)$ \\
\hline Park et al. ${ }^{56}$ & 161 & DS & & & & $12(7)$ \\
\hline Taverna et al. ${ }^{14}$ & 26 & DS & 0 & 0 & $1(4)$ & 0 \\
\hline Kim et al. ${ }^{80}$ & 110 & DS & $3(3)$ & 0 & $5(5)$ & $3(3)$ \\
\hline Van der Linde et al. ${ }^{95}$ & 70 & DS & $24(35)$ & & & $24(35)$ \\
\hline Gasparini et al. $^{91}$ & 143 & DS & $19(13)$ & $14(10)$ & & $33(23)$ \\
\hline Kemp et al. ${ }^{87}$ & 40 & DS & $2(5)$ & $6(14)$ & & $8(20)$ \\
\hline Ahmed et al. ${ }^{88}$ & 302 & DS & $38(13)$ & $15(5)$ & & $40(13)$ \\
\hline Kim et al. ${ }^{52}$ & 34 & DS & $2(6)$ & 0 & & $2(6)$ \\
\hline Sommaire et al. ${ }^{86}$ & 77 & DS requiring revision surgery & $4(5)$ & $8(10)$ & & $12(16)$ \\
\hline Milano et al. ${ }^{94}$ & 70 & Dislocation & $3(4)$ & & & $3(4)$ \\
\hline Owens et al. ${ }^{57}$ & 41 & $\begin{array}{l}\text { Dislocation requiring manual } \\
\text { reduction, subluxation, or } \\
\text { revision }\end{array}$ & $6(15)$ & $9(22)$ & & $15(37)$ \\
\hline Mohtadi et al. ${ }^{89}$ & 28 & $\begin{array}{l}\text { Self-report of } 2 \text { subluxation } \\
\text { events or } 1 \text { dislocation }\end{array}$ & 0 & $2(7)$ & & $2(7)$ \\
\hline Shin et al. ${ }^{90}$ & 63 & $\begin{array}{c}\text { Dislocation or symptomatic } \\
\text { instability }\end{array}$ & $10(16)$ & $2(3)$ & & $12(19)$ \\
\hline Tordjman et al. ${ }^{54}$ & 31 & $\begin{array}{l}\text { Walch-Duplay }(<51 \text { points })+ \\
\text { DS or Apprehension }+ \text { feeling } \\
\text { of instability }\end{array}$ & $5(16)$ & $3(10)$ & & $8(26)$ \\
\hline Robinson et al. ${ }^{92}$ & 42 & $\begin{array}{l}\text { Radiographic dislocation/ } \\
\text { subjective slipping or } \\
\text { apprehension/Apprehension } \\
\text { and load-and-shift test }+\end{array}$ & $3(7)$ & & & $3(7)$ \\
\hline Lee et al. ${ }^{59}$ & 170 & DS & $12(7)$ & $20(12)$ & $20(12)$ & $32(19)$ \\
\hline Torrance et al. ${ }^{15}$ & 67 & $\begin{array}{l}\text { Dislocation or a subjective } \\
\text { feeling of instability with } \\
\text { objective clinical apprehension } \\
\text { requiring further treatment }\end{array}$ & & & & $34(51)$ \\
\hline Vermeulen et al. ${ }^{60}$ & 147 & DS & $21(14)$ & $12(8)$ & & $33(22)$ \\
\hline Chan et al. ${ }^{16}$ & 131 & DS & $22(17)$ & $12(9)$ & & $34(26)$ \\
\hline Park et al. ${ }^{61}$ & 193 & DS requiring revision surgery & & $6(3)$ & & $13(7)$ \\
\hline Ruiz Ibán et al. ${ }^{17}$ & 140 & DS & & & $14(10)$ & $20(14)$ \\
\hline Su et al. ${ }^{18}$ & 65 & DS & & & & $27(42)$ \\
\hline Dickens et al. ${ }^{19}$ & 29 & DS & & & & $1(3)$ \\
\hline Chen et al. ${ }^{20}$ & 221 & $\begin{array}{l}\text { Dislocation or subluxation } \\
\text { event that occurred within } \\
2 \text { years after surgery }\end{array}$ & & & & $31(14)$ \\
\hline Moore et al. ${ }^{21}$ & 34 & DS & $1(3)$ & $2(6)$ & & $3(9)$ \\
\hline Yapp et al. ${ }^{62}$ & 32 & DS & $4(12)$ & $3(9)$ & & $7(21)$ \\
\hline Rhee et al. ${ }^{63}$ & 48 & DS requiring revision surgery & $1(2)$ & $3(6)$ & & $1(2)$ \\
\hline Oh et al. ${ }^{64}$ & 120 & $\begin{array}{l}\text { Dislocation or positive } \\
\text { apprehension }\end{array}$ & $12(10)$ & & $14(12)$ & $26(22)$ \\
\hline Ono et al. ${ }^{65}$ & 51 & DS & $9(18)$ & & $7(14)$ & $16(31)$ \\
\hline Nakagawa et al. ${ }^{22}$ & 140 & DS & & & & $25(18)$ \\
\hline Iizawa et al. 66 & 68 & DS & $17(25)^{\dagger}$ & & & $17(25)^{\dagger}$ \\
\hline Lavoué et al. ${ }^{23}$ & 41 & DS & $1(2)$ & $4(10)$ & $11(27)$ & $5(1)$ \\
\hline Pandey et al. ${ }^{25}$ & 136 & DS & $15(11.0)$ & & & $15(11)$ \\
\hline Brzóska et al. ${ }^{67}$ & 100 & DSA & & & & $14(14)$ \\
\hline
\end{tabular}


Table 2. Continued

\begin{tabular}{|c|c|c|c|c|c|c|}
\hline Study & $\begin{array}{l}\text { Patients } \\
\text { Undergoing } \\
\text { Arthroscopic } \\
\text { Treatment }\end{array}$ & $\begin{array}{l}\text { Definition of } \\
\text { recurrence }\end{array}$ & $\begin{array}{l}\text { Dislocation } \\
\mathrm{N}(\%)\end{array}$ & $\begin{array}{l}\text { Subluxation } \\
\mathrm{N}(\%)\end{array}$ & $\begin{array}{l}\text { Apprehension } \\
\mathrm{N}(\%)\end{array}$ & $\begin{array}{l}\text { Recurrence of } \\
\text { Instability N (\%) }\end{array}$ \\
\hline Gül et al. ${ }^{27}$ & 62 & Dislocation & $5(8)$ & & $8(13)$ & $5(8)$ \\
\hline Jeon et al. ${ }^{30}$ & 118 & DSA & & & & $27(23)$ \\
\hline $\mathrm{O}^{\prime}$ Neill et al. ${ }^{11}$ & 20 & DSA & & & & $8(40)$ \\
\hline Zimmermann et al. ${ }^{31}$ & 271 & DS & $36(13)$ & $51(19)$ & $78(29)$ & $87(32)$ \\
\hline Flinkkilä et al. ${ }^{32}$ & 167 & DS & & & & $50(30)$ \\
\hline McRae et al. ${ }^{96}$ & 74 & $\begin{array}{l}\text { At least one re-dislocation or } \\
\text { minimum of } 2 \text { subluxations } 6 \\
\text { weeks after operation }\end{array}$ & & & & $15(20)$ \\
\hline Castagna et al..$^{70}$ & 65 & DS & & & & $14(21)$ \\
\hline Thomazeau et al. ${ }^{36}$ & 125 & DS & $2(2)$ & $2(2)$ & & $4(3)$ \\
\hline Kim et al. ${ }^{37}$ & 59 & DS & & & $3(5)$ & $4(7)$ \\
\hline Ozbaydar et al. ${ }^{71}$ & 93 & DS & & & & $10(11)$ \\
\hline Boileau et al. ${ }^{72}$ & 91 & DS & $6(7)$ & $8(9)$ & $9(10)$ & $14(15)$ \\
\hline Calvo et al. ${ }^{73}$ & 61 & DS & & & & $11(18)$ \\
\hline Kim et al. ${ }^{97}$ & 62 & DSA & $0(0)$ & $0(0)$ & $4(6)$ & $4(6)$ \\
\hline Kim et al. ${ }^{74}$ & 167 & DSA & $1(1)$ & $2(1)$ & $4(2)$ & $7(4)$ \\
\hline Sperber et al. ${ }^{38}$ & 30 & DS & & & 0 & $7(23)$ \\
\hline Nakagawa et al. ${ }^{39}$ & 257 & DS & & & & $42(16)$ \\
\hline Nakagawa et al. ${ }^{40}$ & 93 & DS & & & & $22(24)$ \\
\hline Chechik et al. ${ }^{41}$ & 83 & DS & $9(11)$ & $7(8)$ & & $16(19)$ \\
\hline Kim et al. ${ }^{78}$ & 36 & DSA & $1(3)$ & $2(6)$ & $1(3)$ & $4(11)$ \\
\hline McCabe et al. ${ }^{45}$ & 31 & $\begin{array}{l}\text { Dislocation, subluxation or } \\
\text { revision instability surgery }\end{array}$ & $1(3)$ & $3(10)$ & & $11(36)$ \\
\hline Ng and Kumar ${ }^{79}$ & 87 & DSA & $2(2)$ & & & $2(2)$ \\
\hline Ee et al. ${ }^{81}$ & 79 & $\begin{array}{l}\text { Redislocation, any sensation of } \\
\text { subluxation, or instability } \\
\text { preventing return to full } \\
\text { activity or requiring a further } \\
\text { stabilizing procedure }\end{array}$ & $6(8)$ & & & $6(8)$ \\
\hline Boileau et al. ${ }^{47}$ & 19 & DS & & $1(5)$ & $2(11)$ & $1(5)$ \\
\hline Sedeek et al. ${ }^{48}$ & 40 & $\begin{array}{c}\text { Recurrent dislocation, } \\
\text { symptomatic subluxation or } \\
\text { instability preventing return to } \\
\text { full active duties or } \\
\text { necessitating an additional } \\
\text { surgical stabilization } \\
\text { procedure. }\end{array}$ & & & & $3(8)$ \\
\hline Phadnis et al. ${ }^{49}$ & 141 & $\begin{array}{l}\text { Recurrence of subluxation or } \\
\text { frank dislocation or an } \\
\text { ongoing or new feeling of } \\
\text { instability }\end{array}$ & $12(9)$ & & & $19(13)$ \\
\hline
\end{tabular}


Table 2. Continued

\begin{tabular}{|c|c|c|c|c|c|c|}
\hline $\begin{array}{c}\text { Study } \\
\end{array}$ & $\begin{array}{c}\text { Patients } \\
\text { Undergoing } \\
\text { Arthroscopic } \\
\text { Treatment }\end{array}$ & $\begin{array}{c}\text { Definition of } \\
\text { recurrence }\end{array}$ & $\begin{array}{c}\text { Dislocation } \\
\mathrm{N}(\%)\end{array}$ & $\begin{array}{c}\text { Subluxation } \\
\text { N (\%) }\end{array}$ & $\begin{array}{c}\text { Apprehension } \\
\text { N (\%) }\end{array}$ & $\begin{array}{c}\text { Recurrence of } \\
\text { Instability } \mathrm{N}(\%)\end{array}$ \\
\hline Franceschi et al. $^{50}$ & 50 & $\begin{array}{l}\text { Subluxation, } 1 \text { or more frank } \\
\text { dislocations, or at least } 1 \\
\text { episode of dead arm syndrome }\end{array}$ & $3(6)$ & $2(4)$ & $5(10)$ & $5(10)$ \\
\hline Zhu et al. ${ }^{82}$ & 49 & DSA & l (2) & $2(4)$ & $1(2)$ & $4(8)$ \\
\hline Mohtadi et al. ${ }^{83}$ & 87 & DS & $16(18)$ & $4(5)$ & & $20(23)$ \\
\hline Zaffagnini et al. ${ }^{51}$ & 49 & redislocation & $6(12)$ & & & $6(12)$ \\
\hline Elmlund et al. ${ }^{84}$ & 76 & DS & $8(11)$ & $6(8)$ & $6(8)$ & $14(18)$ \\
\hline Carreira et al. $^{85}$ & 85 & DS & $4(6)$ & $3(4)$ & $2(3)$ & $7(10)$ \\
\hline Gigis et al. ${ }^{102}$ & 38 & DS & & & $4(11)$ & $5(13)$ \\
\hline Shymon et al. ${ }^{103}$ & 71 & $\begin{array}{l}\text { redislocation event and/or the } \\
\text { need for further surgical } \\
\text { intervention }\end{array}$ & & & & $17(24)$ \\
\hline
\end{tabular}

*Only reported on dislocations.

${ }^{\dagger}$ In a table the number is expressed as dislocations, while in the text as dislocations and subluxations.

apprehension (DSA). Fifty-two studies reported the definition of a recurrence as DS and 15 studies as DSA. The remaining 24 studies used 15 different definitions of a recurrence (Table 2 ).

\section{Recurrence Rates Reported}

Recurrence rates, as well as the rates of dislocation, subluxation and positive apprehension test results for each article, are reported in Table 2. In Park et al., ${ }^{56}$ we could not extract the exact number of recurrent dislocations because only the amount of dislocations in group 1 were reported. Thirty studies $(33 \%)$ did not report on recurrent dislocations, 45 studies $(49 \%)$ did

Table 3. Definitions of Dislocation and Subluxation

\footnotetext{
Definition of dislocation

Dislocation needing reduction (by medical professional or third party) $12,16,19,26,31,33,34,37,57,58,68,70,72-74,87,91,102$

Objective documentation of a dislocation either radiologically or clinically ${ }^{24,32,59,62,71,75,92}$

Increased translation of the humerus relative to the glenoid to the point of complete separation of articular surfaces ${ }^{96}$

More than 1 episode of instability which needed manual reduction by other people ${ }^{97}$

Definition of subluxation

Instability without the need of reduction $^{12,13,16,26,31,33,34,45,57,58,68,70,72,87,91,97,102}$

Subjective sense of subluxation/instability ${ }^{24,37,44,60,69,71,99}$

Sense of dislocation with a positive anterior apprehension test ${ }^{59}$

Transient instability event that did not require reduction but demonstrated a positive apprehension and relocation sign with radiographic or magnetic resonance imaging evidence of a Bankart or Hill-Sachs ${ }^{19}$

Symptomatic self-reported subluxation ${ }^{62}$

"Dead-arm" phenomenon or instability which spontaneously reduced $^{73,75}$

Symptomatic translation of the humeral head relative to the glenoid articular surface without a dislocation ${ }^{96}$

Subluxation at the time of the clinical assessment or through a history of at least 1 episode of dead arm syndrome ${ }^{84}$
}

not report on recurrent subluxation, and 58 studies $(64 \%)$ did not report on apprehension.

Overall recurrence rates ranged from $0 \%$ to $55 \%$, dislocation rates from $0 \%$ to $35 \%$, subluxation rates from $0 \%$ to $25 \%$, and apprehension rates from $0 \%$ to $29 \%$. The articles using the DSA definition had a total of 20 dislocations $(2 \%$ from the studies reporting on dislocations), 8 subluxations ( $1 \%), 26$ positive apprehension tests $(3 \%)$ with an overall 107 recurrences (11\%), whereas the studies defining recurrence as DS had 369 dislocations (7\%), 225 subluxations (4\%), 194 positive apprehension tests $(3 \%)$, and an overall 1,006 recurrences $(18 \%)$. Overall recurrence, dislocation, subluxation, and apprehension rates are shown in Figures 2 through 5. The articles varied in their reporting of dislocation, subluxation, and apprehension on the basis of the definitions of recurrence used (Table 4).

\section{Discussion}

The results of this study show that there are no uniform definitions of recurrence, subluxation, or dislocation after shoulder stabilization surgery used in the current literature. Using different definitions leads to a high level of heterogeneity. This could lead to misinterpretation of results and conclusions.

\section{Recommendations}

To optimize readability and comparability of studies, we have made recommendations regarding the definitions of (recurrent) instability, dislocation, subluxation, and apprehension. For dislocations, we suggest the definition of a radiographically confirmed dislocation or a dislocation that is manually reduced. For this definition the shoulders reduced by a care giver or by patients themselves should be differentiated. To avoid underreporting of dislocations, all self-reported dislocation 
Recurrence (\%)

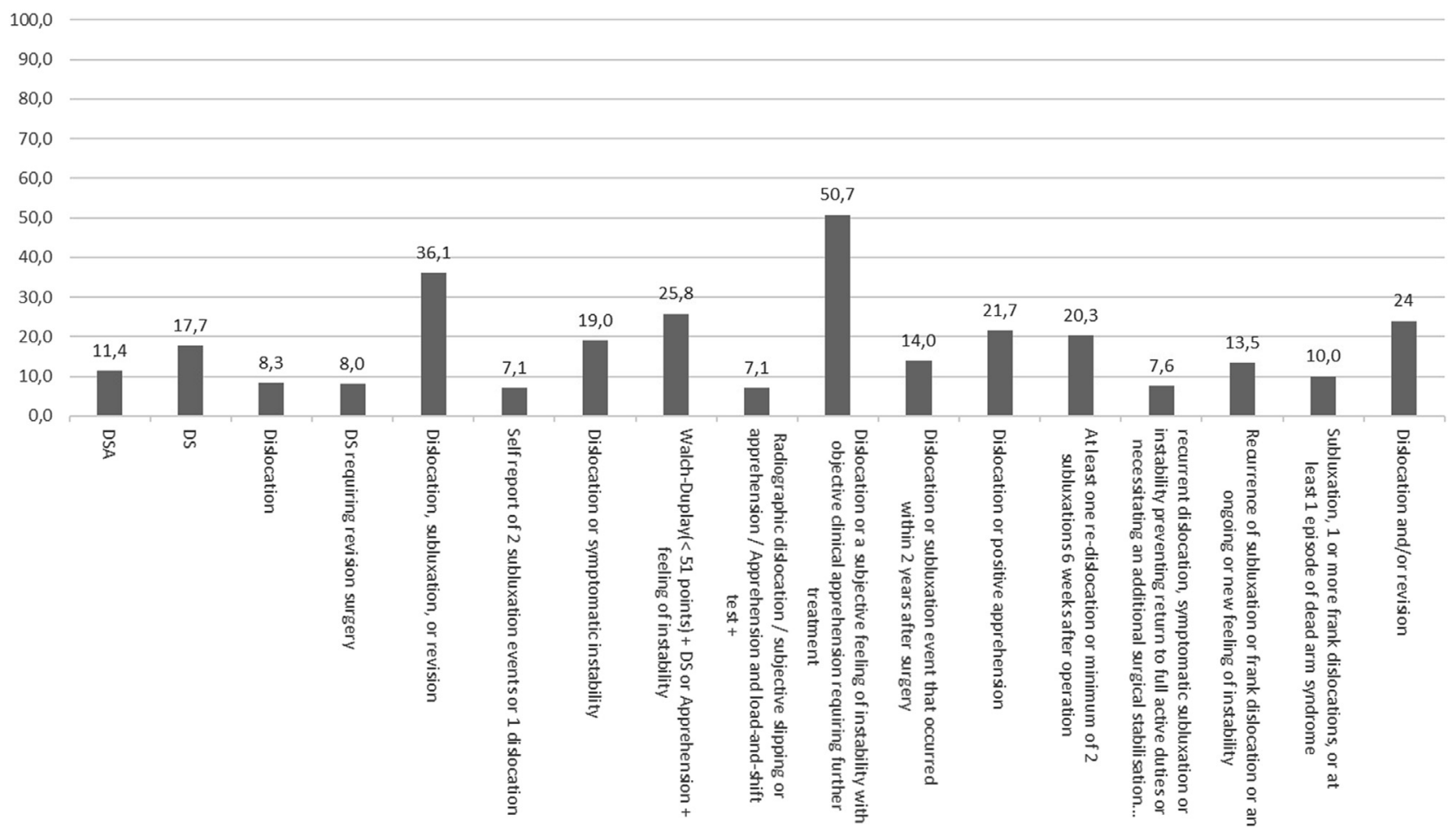

Fig 2. Recurrence percentage for each definition. This figure shows the percentage of recurrence for each definition of recurrence: on the $\mathrm{X}$-axis we have the different definitions and on the Y-axis the percentage of patients who have suffered a recurrence. When no percentage is reported, it means that it has not been reported in any study.

Dislocation (\%)

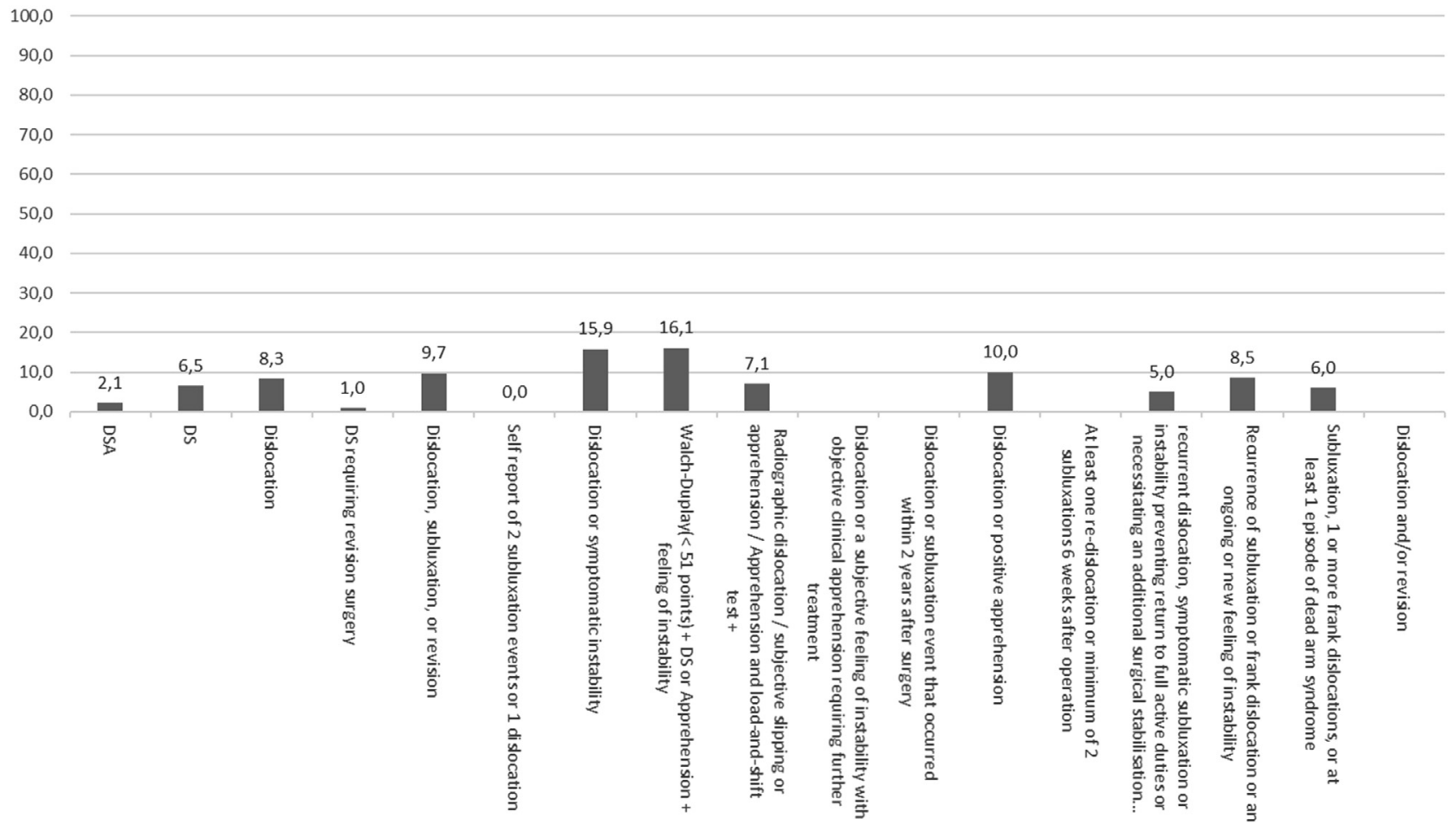

Fig 3. Dislocation percentage for each definition. This figure shows the percentage of dislocations for each definition of recurrence: on the X-axis we have the different definitions and on the Y-axis the percentage of patients who have suffered a dislocation. When no percentage is reported, it means that it has not been reported in any study. 
Subluxation (\%)

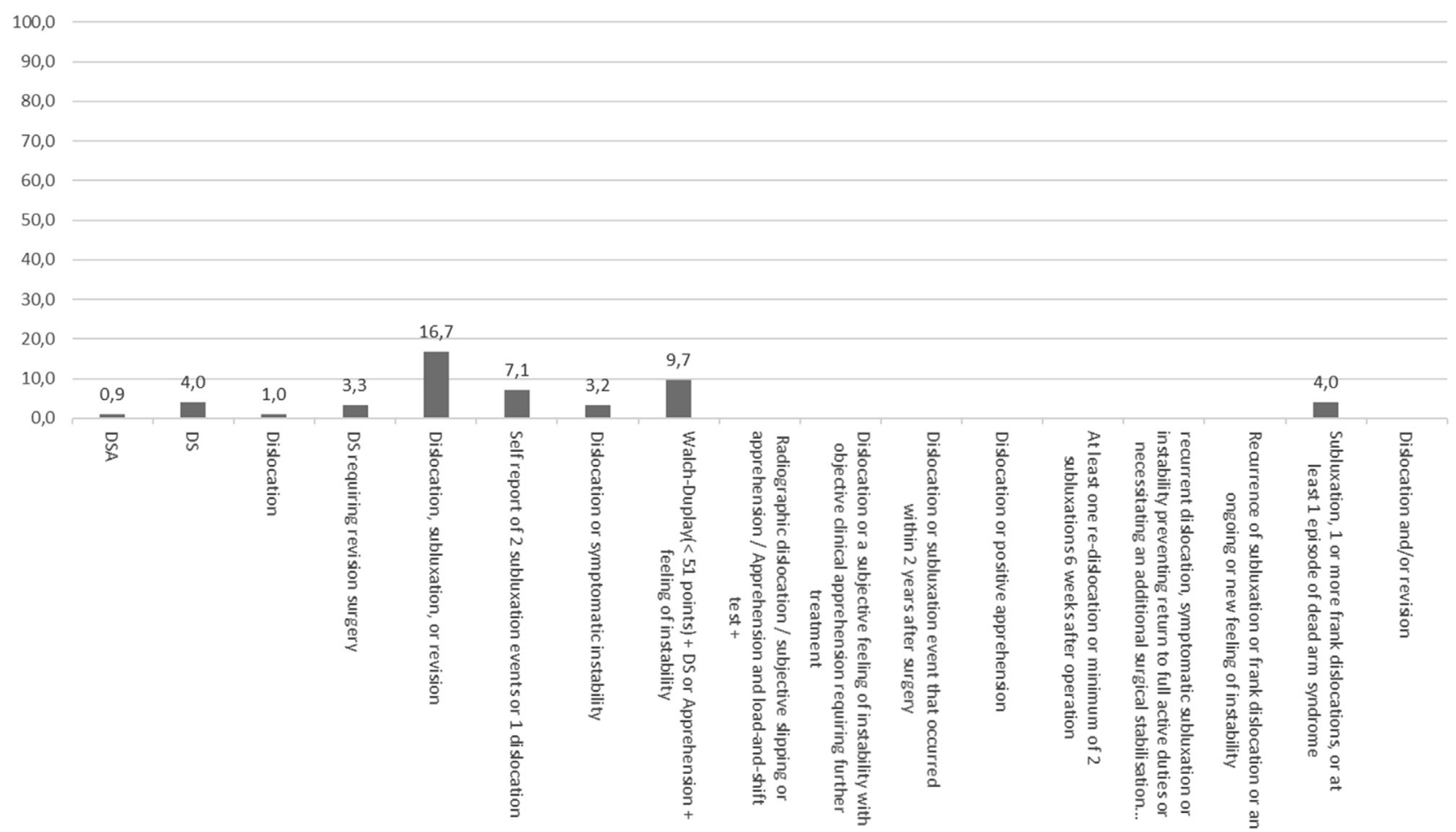

Fig 4. Subluxation percentage for each definition. This figure shows the percentage of subluxations for each definition of recurrence: on the X-axis we have the different definitions, and on the Y-axis the percentage of patients who have suffered a subluxation. When no percentage is reported, it means that it has not been reported in any study.

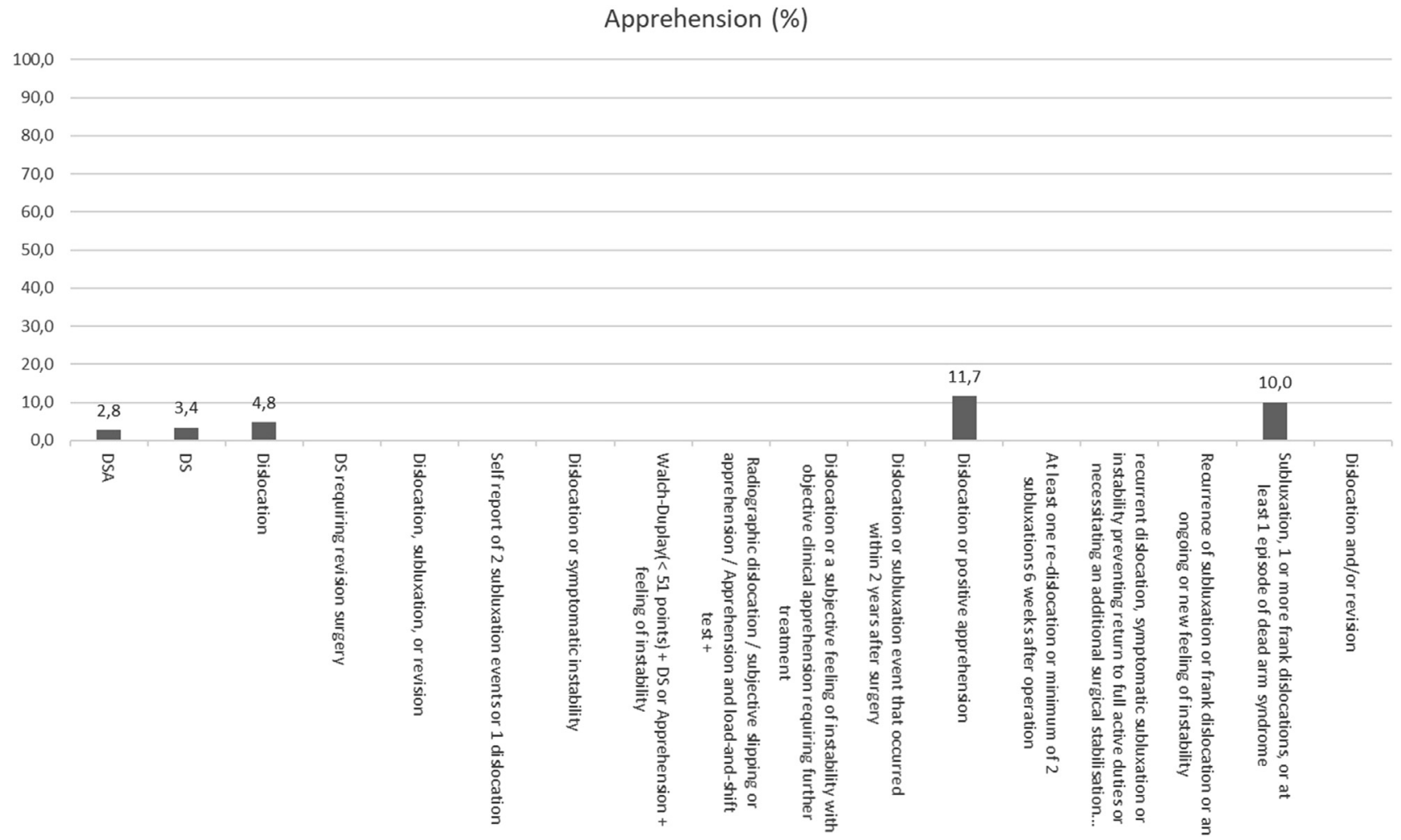

Fig 5. Apprehension percentage for each definition. This figure shows the percentage of apprehension for each definition of recurrence: on the $\mathrm{X}$-axis we have the different definitions, and on the Y-axis the percentage of patients having a positive apprehension sign. When no percentage is reported, it means that it has not been reported in any study. 
Table 4. Number of Dislocations, Subluxations and Recurrences Per Definition

\begin{tabular}{|c|c|c|c|c|c|}
\hline Definition & Total & $\begin{array}{l}\text { Dislocation } \\
\mathrm{N}(\%)\end{array}$ & $\begin{array}{l}\text { Subluxation } \\
\mathrm{N}(\%)\end{array}$ & Apprehension $(\mathrm{N})$ & $\begin{array}{l}\text { Recurrence of } \\
\text { Instability }(\mathrm{N})\end{array}$ \\
\hline DSA & 938 & $20(2)$ & $8(1)$ & $26(3)$ & $107(11)$ \\
\hline DS & 5681 & $369(7)$ & $225(4)$ & $194(3)$ & $1,006(18)$ \\
\hline DS requiring revision surgery & 513 & $5(1)$ & $17(3)$ & & $41(8)$ \\
\hline Dislocation, subluxation, or revision & 72 & $7(10)$ & $12(17)$ & & $26(36)$ \\
\hline Self-report of 2 subluxation events or 1 dislocation & 28 & $0(0)$ & $2(7)$ & & $2(7)$ \\
\hline $\begin{array}{l}\text { Radiographic dislocation/subjective slipping or } \\
\text { apprehension/Apprehension and load-and-shift test }+\end{array}$ & 42 & $3(7)$ & & & $3(7)$ \\
\hline $\begin{array}{l}\text { Dislocation or a subjective feeling of instability with } \\
\text { objective clinical apprehension requiring further } \\
\text { treatment }\end{array}$ & 67 & & & & $34(51)$ \\
\hline $\begin{array}{l}\text { Recurrent dislocation, symptomatic subluxation or } \\
\text { instability preventing return to full active duties or } \\
\text { necessitating an additional surgical stabilization } \\
\text { procedure. }\end{array}$ & 119 & $6(5)$ & & & $9(8)$ \\
\hline $\begin{array}{l}\text { Recurrence of subluxation or frank dislocation or an } \\
\text { ongoing or new feeling of instability }\end{array}$ & 141 & $12(9)$ & & & $19(13)$ \\
\hline $\begin{array}{l}\text { Subluxation, } 1 \text { or more frank dislocations, or at least } 1 \\
\text { episode of dead arm syndrome }\end{array}$ & 50 & $3(6)$ & $2(4)$ & $5(10)$ & $5(10)$ \\
\hline Dislocation or revision & 71 & & & & $17(24)$ \\
\hline
\end{tabular}

Percentages are percentages of total patients in studies mentioned to have an event (e.g., if a study does not report on subluxations, it is not used to calculate the percentage of subluxations)

with signs of a sustained dislocation in further radiographs, such as Hill-Sachs or bony Bankart lesion in comparison with the preoperative situation, could be categorized as a confirmed dislocation. For subluxations, we advise using the definition of the feeling of a dislocation that can be (spontaneously) reduced without the need for a radiographically confirmed dislocation. For a positive apprehension sign, we suggest using the definition as mentioned by Lädermann et al. ${ }^{100}$ as fear of imminent dislocation when placing the arm in abduction and external rotation during physical examination. We suggest not using the definition recurrence of instability anymore to avoid using multiple meanings of this term; if used we suggest using the definition as a dislocation or a subluxation and also report on these events separately. We chose this definition because of the fact that dislocations and subluxations can be regarded as a (partial) failure of the operation, whereas a positive apprehension test result does not always correlate with instability of the shoulder. This is because a positive apprehension could be related to changes in functional cerebral networks induced by prior instability that can persist even after stabilizing the shoulder. ${ }^{101}$ Finally, we endorse reporting on the events resulting in a dislocation or subluxation to be able to make an estimation of the severity of instability. For example, a shoulder that dislocates during normal daily activities is potentially more unstable in comparison with a shoulder dislocating after a collision during sports.

\section{Limitations}

Although DSA and DS have significantly different recurrence rates, the high number of studies not reporting dislocations, subluxations, and apprehension rates separately makes it unknown whether the recurrence rates would remain similar if all studies held the same criteria for defining recurrences in their cohort (e.g., not including apprehension in the definition could lead in less-reported recurrences). Because of corrections for multiple comparisons being not feasible for 17 definitions and because of the high variability in surgical techniques and patient characteristics, we did not compare the results for the different definitions. Remarkably, we had to exclude $68 \%$ of eligible studies because recurrence rates were not defined at all.

Another limitation of this study is that we could not compare the results of the different techniques to assess whether other definitions could lead to other results. We agree with the results $\mathrm{Kuhn}^{7}$ and Kennedy et al. ${ }^{8}$ The difference with Kennedy et al. ${ }^{8}$ is that we were stricter in whether a definition is explicitly defined to 
avoid overestimation of the reporting of recurrence rates; for example, in Kennedy et al. ${ }^{8}$ an article was regarded as defining recurrences as a dislocation if they only reported on dislocations without explicitly defining recurrences. Kasik and Saper ${ }^{101}$ have also reported that there are different definitions of recurrences after arthroscopic Bankart repair in the adolescent athletes. However, just like the article of Kennedy et al., ${ }^{8}$ they also included articles that do not define recurrences explicitly.

\section{Conclusion}

Recurrence rates are poorly specified and likely underreported in the literature, hampering comparison with results of other studies. This highlights the need for a consensus on definition of recurrence across shoulder instability studies. We recommend not using the definition recurrence of instability anymore. We endorse defining dislocations as a radiographically confirmed dislocation or a dislocation that is manually reduced, subluxations as the feeling of a dislocation that can be (spontaneously) reduced without the need for a radiographically confirmed dislocation, and a positive apprehension sign as fear of imminent dislocation when placing the arm in abduction and external rotation during physical examination. Reporting on the events resulting in a dislocation or subluxation aids in making an estimation of the severity of instability.

\section{References}

1. Coyner KJ, Arciero RA. Shoulder instability: anterior, posterior, multidirectional, arthroscopic versus open, bone block procedures. Sport Med Arthrosc Rev 2018;26: 168-170.

2. Froda S de, Bokshan S, Stern E, Sullivan K, Owens BD. Arthroscopic Bankart repair for the management of anterior shoulder instability: indications and outcomes. Curr Rev Musculoskelet Med 2017;10:442-451.

3. Bhatia S, Frank RM, Ghodadra NS, et al. The outcomes and surgical techniques of the Latarjet procedure. Arthroscopy 2014;30:227-235.

4. Gerometta A, Rosso C, Klouche S, Hardy P. Arthroscopic Bankart shoulder stabilization in athletes: return to sports and functional outcomes. Knee Surgery, Sport Traumatol Arthrosc 2016;24:1877-1883.

5. Randelli P, Ragone V, Carminati S, Cabitza P. Risk factors for recurrence after Bankart repair a systematic review. Knee Surg Sports Traumatol Arthrosc 2012;20:2129-2138.

6. Gastel ML van, Willigenburg NW, Dijksman LM, et al. Ten percent re-dislocation rate 13 years after the arthroscopic Bankart procedure. Knee Surg Sport Traumatol Arthrosc 2019;27:3929-3936.

7. Kuhn JE. A new classification system for shoulder instability. Br J Sport Med 2010;44:341-346.

8. Kennedy MI, Murphy C, Dornan GJ, et al. Variability of reporting recurrence after arthroscopic Bankart repair: a call for a standardized study design. Orthop J Sport Med 2019;7:2325967119846915.
9. Liberati A, Altman DG, Tetzlaff J, et al. The PRISMA statement for reporting systematic reviews and metaanalyses of studies that evaluate health care interventions: explanation and elaboration. PLoS Med 2009; 6:e1000100.

10. Altman DG, Schulz KF, Moher D, Egger M, Davidoff F, Elbourne D. The revised CONSORT statement for reporting randomized trials: explanation and elaboration. Ann Intern Med 2001;134:663-694.

11. O'Neill DC, Christensen G, Kawakami J, et al. Revision anterior glenohumeral instability: is arthroscopic treatment an option? JSES Int 2020;4:287-291.

12. Thal R, Nofziger M, Bridges M, Kim JJ. Arthroscopic Bankart repair using knotless or bioknotless suture anchors: 2- to 7-year results. Arthroscopy 2007;23: 367-375.

13. Law BK-Y, Yung PS-H, Ho EP-Y, Chang JJH-T, Chan K-M. The surgical outcome of immediate arthroscopic Bankart repair for first time anterior shoulder dislocation in young active patients. Knee Surg Sports Traumatol Arthrosc 2008;16: 188-193.

14. Taverna E, Garavaglia G, Perfetti C, Ufenast H, Sconfienza LM, Guarrella V. An arthroscopic bone block procedure is effective in restoring stability, allowing return to sports in cases of glenohumeral instability with glenoid bone deficiency. Knee Surg Sports Traumatol Arthrosc 2018;26:3780-3787.

15. Torrance E, Clarke CJ, Monga P, Funk L, Walton MJ. Recurrence after arthroscopic labral repair for traumatic anterior instability in adolescent rugby and contact athletes. Am J Sports Med 2018;46:2969-2974.

16. Chan AG, Kilcoyne KG, Chan S, Dickens JF, Waterman BR. Evaluation of the Instability Severity Index score in predicting failure following arthroscopic Bankart surgery in an active military population. J shoulder Elb Surg 2019;27:3905-3911.

17. Ruiz Ibán MA, Asenjo Gismero CV, Moros Marco S, et al. Instability severity index score values below 7 do not predict recurrence after arthroscopic Bankart repair. Knee Surg Sports Traumatol Arthrosc 2019;27:3905-3911.

18. Su F, Kowalczuk M, Ikpe S, Lee H, Sabzevari S, Lin A. Risk factors for failure of arthroscopic revision anterior shoulder stabilization. J Bone Jt Surg 2018;100: 1319-1325.

19. Dickens JF, Rue JP, Cameron KL, et al. Successful return to sport after arthroscopic shoulder stabilization versus nonoperative management in contact athletes with anterior shoulder instability: a prospective multicenter study. Am J Sport Med 2017;45:2540-2546.

20. Chen KH, Yang TC, Chiang ER, Wang HY, Ma HL. The Hill-Sachs interval to glenoid track width ratio is comparable to the instability severity index score for predicting risk of recurrent instability after arthroscopic Bankart repair. Knee Surgery. Sport Traumatol Arthrosc 2021;29:250-256.

21. Moore TK, Hurley ET, Rowe DN, et al. Outcomes following arthroscopic Bankart repair in female patients. J Shoulder Elb Surg 2020;29:1332-1336.

22. Nakagawa S, Hirose T, Uchida R, Tanaka M, Mae T. Postoperative recurrence of instability after arthroscopic Bankart repair for shoulders with primary instability 
compared with recurrent instability: influence of bipolar bone defect size. Am J Sports Med 2020;48:48-55.

23. Lavoué V, Gendre P, Saliken D, Brassac A, Boileau P. The role of arthroscopic soft tissue reconstruction for failed Bristow-Latarjet procedure. Arthroscopy 2019;35: 2581-2588.

24. Porcellini G, Campi F, Pegreffi F, Castagna A, Paladini P. Predisposing factors for recurrent shoulder dislocation after arthroscopic treatment. J Bone Jt Surg 2009;91: 2537-2542.

25. Pandey V, Gangadharaiah L, Madi S, et al. A retrospective cohort analysis of arthroscopic Bankart repair with or without remplissage in patients with offtrack Hill-Sachs lesion evaluated for functional outcomes, recurrent instability, and range of motion. J Shoulder Elbow Surg 2020;29:273-281.

26. Ernstbrunner L, De Nard B, Olthof M, et al. Long-term results of the arthroscopic Bankart repair for recurrent anterior shoulder instability in patients older than 40 years: a comparison with the open Latarjet procedure. Am J Sports Med 2020;48:2090-2096.

27. Gül O, Okutan AE, Ayas MS. Arthroscopic glenoid labral lesion repair using all-suture anchor for traumatic anterior shoulder instability: short-term results. J Shoulder Elbow Surg 2019;28:1991-1997.

28. Loppini M, Delle Rose G, Borroni M, et al. Is the Instability Severity Index Score a valid tool for predicting failure after primary arthroscopic stabilization for anterior glenohumeral instability? Arthroscopy 2019;35: 361-366.

29. Park I, Kang J-S, Jo Y-G, Shin S-J. Factors related to patient dissatisfaction versus objective failure after arthroscopic shoulder stabilization for instability. J Bone Jt Surg Am 2019;101:1070-1076.

30. Jeon YS, Jeong HY, Lee DK, Rhee YG. Borderline glenoid bone defect in anterior shoulder instability: Latarjet procedure versus bankart repair. Am J Sports Med 2018;46:2170-2176.

31. Zimmermann SM, Scheyerer MJ, Farshad M, Catanzaro S, Rahm S, Gerber C. Long-term restoration of anterior shoulder stability: a retrospective analysis of arthroscopic Bankart repair versus open Latarjet procedure. J Bone Jt Surg Am 2016;98:1954-1961.

32. Flinkkilä T, Knape R, Sirniö K, Ohtonen P, Leppilahti J. Long-term results of arthroscopic Bankart repair: minimum 10 years of follow-up. Knee Surg Sport Traumatol Arthrosc 2018;26:94-99.

33. Bessière C, Trojani C, Carles M, Mehta SS, Boileau P. The open Latarjet procedure is more reliable in terms of shoulder stability than arthroscopic Bankart repair. Clin Orthop Rel Res 2014;472:2345-2351.

34. Bessière C, Trojani C, Pélégri C, Carles M, Boileau P. Coracoid bone block versus arthroscopic Bankart repair: a comparative paired study with 5-year follow-up. Orthop Traumatol Surg Res 2013;99:123-130.

35. Lützner J, Krummenauer F, Lübke J, Kirschner S, Günther K-P, Bottesi M. Fuctional outcome after open and arthroscopic bankart repair for traumatic shoulder instability. Eur J Med Res 2009;14:18-24.

36. Thomazeau H, Courage O, Barth J, et al. Can we improve the indication for Bankart arthroscopic repair? A preliminary clinical study using the ISIS score. Orthop Traumatol Surg Res 2010;96:S77-S83.

37. Kim SJ, Jung M, Moon HK, Chang WH, Kim SG, Chun YM. Is the transglenoid suture technique recommendable for recurrent shoulder dislocation? A minimum 5-year follow-up in 59 non-athletic shoulders. Knee Surg Sport Traumatol Arthrosc 2009;17:1458-1462.

38. Sperber A, Hamberg P, Karlsson J, Swärd L, Wredmark T. Comparison of an arthroscopic and an open procedure for posttraumatic instability of the shoulder: a prospective, randomized multicenter study. J Shoulder Elbow Surg 2001:10:105-108.

39. Nakagawa S, Hirose T, Tachibana $Y$, Iuchi $R$, Mae $T$. Postoperative recurrence of instability due to new anterior glenoid rim fractures after arthroscopic Bankart repair. Am J Sports Med 2017;45:2840-2848.

40. Nakagawa S, Mae T, Yoneda K, Kinugasa K, Nakamura H. Influence of glenoid defect size and bone fragment size on the clinical outcome after arthroscopic Bankart repair in male collision/contact athletes. Am J Sports Med 2017;45:1967-1974.

41. Chechik O, Maman E, Dolkart O, Khashan M, Shabtai L, Mozes G. Arthroscopic rotator interval closure in shoulder instability repair: a retrospective study. J Shoulder Elbow Surg 2010;19:1056-1062.

42. Anderl W, Pauzenberger L, Laky B, Kriegleder B, Heuberer PR. Arthroscopic implant-free bone grafting for shoulder instability with glenoid bone loss. Am J Sports Med 2015;44:1137-1145.

43. De Giorgi S, Garofalo R, Tafuri S, Cesari E, Rose GD, Castagna A. Can arthroscopic revision surgery for shoulder instability be a fair option? Muscles Ligaments Tendons J 2014;14:226-231:4.

44. Garcia GH, Park MJ, Zhang C, Kelly JD, Huffman GR. Large Hill-Sachs lesion: a comparative study of patients treated with arthroscopic Bankart repair with or without remplissage. HSS J 2015;11:98-103.

45. McCabe MP, Weinberg D, Field LD, O'Brien MJ, Hobgood ER, Savoie FH. Primary versus revision arthroscopic reconstruction with remplissage for shoulder instability with moderate bone loss. Arthroscopy 2014;30:444-450.

46. Park MJ, Tjoumakaris FP, Garcia G, Patel A, Kelly JD. Arthroscopic remplissage With Bankart repair for the treatment of glenohumeral instability with Hill-Sachs defects. Arthrosc J Arthrosc Relat Surg 201 1;27:1187-1194.

47. Boileau P, Richou J, Lisai A, Chuinard C, Bicknell RT. The role of arthroscopy in revision of failed open anterior stabilization of the shoulder. Arthroscopy 2009;25: 1075-1084.

48. Sedeek SM, Tey IK, Tan AHC. Arthroscopic Bankart repair for traumatic anterior shoulder instability with the use of suture anchors. Singapore Med J 2008;49:676-681.

49. Phadnis J, Arnold C, Elmorsy A, Flannery M. Utility of the Instability Severity Index Score in predicting failure after arthroscopic anterior stabilization of the shoulder. Am J Sport Med 2015;43:1983-1988.

50. Franceschi F, Papalia R, Rizzello G, et al. Remplissage repair-new frontiers in the prevention of recurrent shoulder instability: a 2-year follow-up comparative study. Am J Sports Med 2012;40:2462-2469. 
51. Zaffagnini S, Marcheggiani Muccioli GM, Giordano G, et al. Long-term outcomes after repair of recurrent posttraumatic anterior shoulder instability: comparison of arthroscopic transglenoid suture and open Bankart reconstruction. Knee Surgery. Sport Traumatol Arthrosc 2012;20:816-821.

52. Kim Y-K, Cho S-H, Son W-S, Moon S-H. Arthroscopic repair of small and medium-sized bony Bankart lesions. Am J Sports Med 2014;42:86-94.

53. Wolf EM, Arianjam A. Hill-Sachs remplissage, an arthroscopic solution for the engaging Hill-Sachs lesion: 2- to 10-year follow-up and incidence of recurrence. J Shoulder Elbow Surg 2014;23:814-820.

54. Tordjman D, Vidal C, Fontès D. Mid-term results of arthroscopic Bankart repair: a review of 31 cases. Orthop Traumatol Surg Res 2016;102:541-548.

55. Cho NS, Yoo JH, Juh HS, Rhee YG. Anterior shoulder instability with engaging Hill-Sachs defects: a comparison of arthroscopic Bankart repair with and without posterior capsulodesis. Knee Surgery. Sport Traumatol Arthrosc 2016;24:3801-3808.

56. Park I, Park C-J, Lee J-H, Hyun H-S, Park J-Y, Shin S-J. Clinical outcomes and recurrence rates after arthroscopic stabilization procedures in young patients with a glenoid bone erosion: a comparative study between glenoid erosion more and less than 20. Arthroscopy 2018;34: 2287-2293.

57. Owens BD, DeBerardino TM, Nelson BJ, et al. Long-term follow-up of acute arthroscopic Bankart repair for initial anterior shoulder dislocations in young athletes. Am J Sports Med 2009;37:669-673.

58. Flinkkilä T, Hyvönen P, Ohtonen P, Leppilahti J. Arthroscopic Bankart repair: results and risk factors of recurrence of instability. Knee Surg Sport Traumatol Arthrosc 2010;18:1752-1758.

59. Lee SH, Lim KH, Kim JW. Risk factors for recurrence of anterior-inferior instability of the shoulder after arthroscopic Bankart repair in patients younger than 30 years. Arthroscopy 2018;34:2530-2536.

60. Vermeulen AE, Landman EBM, Veen EJD, Nienhuis S, Koorevaar CT. Long-term clinical outcome of arthroscopic Bankart repair with suture anchors. J Shoulder Elb Surg 2019;28(5):e137-el43.

61. Park I, Kang J-S, Jo Y-G, Kim S-W, Shin S-J. Off-track Hill-Sachs lesions do not increase postoperative recurrent instability after arthroscopic Bankart repair with selective Remplissage procedure. Knee Surg Sport Traumatol Arthrosc 2019;27:3864-3870.

62. Yapp LZ, Nicholson JA, Robinson CM. Primary arthroscopic stabilization for a first-time anterior dislocation of the shoulder: long-term follow-up of a randomized, double-blinded trial. J Bone Jt Surg Am2020;102:460-467.

63. Rhee YG, Park I, Kim JY, Hyun HS, Shin SJ. Preoperative diagnostic rates and clinical outcomes after arthroscopic stabilization procedures for panlabral tear of the glenohumeral joint. Arthroscopy 2020;36:411-418.

64. Oh JH, Shin SJ, Cho CH, Seo HJ, Park JS, Rhee YG. Reliability of the instability severity index score as a predictor of recurrence after arthroscopic anterior capsulolabral reconstruction: a multicenter retrospective study. CiOS Clin Orthop Surg 2019;11:445-452.
65. Ono Y, Dávalos Herrera DA, Woodmass JM, et al. Long-term outcomes following isolated arthroscopic Bankart repair: a 9- to 12-year follow-up. JSES Open Access 2019;3:189-193.

66. Iizawa N, Yoneda M, Yamada S, et al. Benefits of bone graft augmentation to arthroscopic Bankart repair for recurrent anterior shoulder instability with glenoid bone loss. Knee Surg Sport Traumatol Arthrosc 2020;28: 2325-2333.

67. Brzóska R, Laprus H, Michniowski P, Solecki W, Klon W, Błasiak A. Novel and effective arthroscopic extracapsular stabilization technique for anterior shoulder instabilityBLS. Knee Surg Sport Traumatol Arthrose 2019;27: 3897-3904.

68. Rose GD, Borroni M, Castagna A. The role of arthroscopic capsulo-labral repair in unidirectional posttraumatic shoulder instability in adolescent athletes participating in overhead or contact sports. Joints 2013;1: 108-111.

69. Imhoff AB, Ansah P, Tischer T, et al. Arthroscopic repair of anterior-inferior glenohumeral instability using a portal at the 5:30-o'clock position: analysis of the effects of age, fixation method, and concomitant shoulder injury on surgical outcomes. Am J Sports Med 2010;38: 1795- 1803.

70. Castagna A, Delle Rose G, Borroni M, et al. Arthroscopic stabilization of the shoulder in adolescent athletes participating in overhead or contact sports. Arthroscopy 2012;28:309-315.

71. Ozbaydar M, Elhassan B, Diller D, Massimini D, Higgins LD, Warner JJP. Results of arthroscopic capsulolabral repair: Bankart lesion versus anterior labroligamentous periosteal sleeve avulsion lesion. Arthroscopy 2008;24:1277-1283.

72. Boileau P, Villalba M, Héry J-Y, Balg F, Ahrens P, Neyton L. Risk factors for recurrence of shoulder instability after arthroscopic Bankart repair. J Bone Joint Surg 2006;88:1755.

73. Calvo E, Granizo JJ, Fernández-Yruegas D. Criteria for arthroscopic treatment of anterior instability of the shoulder. A prospective study. J Bone Joint Surg $\mathrm{Br}$ 2005;87:677-683.

74. Kim SH, Ha KI, Cho YB, Ryu BD, Oh I. Arthroscopic anterior stabilization of the shoulder: two to six-year follow-up. J Bone Joint Surg Am 2003;85:151 1-1518.

75. Constantinou CC, Sernert N, Rostgård-Christensen L, Kartus J. Large drill holes are still present in the long term after arthroscopic Bankart repair with absorbable tacks: an 18-year randomized prospective study. Am J Sports Med 2020;48:1865-1872.

76. Armangil M, Basat HÇ, Akan B, Karaduman M, Demirtaş M. Arthroscopic stabilization of anterior shoulder instability using a single anterior portal. Acta Orthop Traumatol Turc 2015;49:6-12.

77. Boughebri O, Maqdes A, Moraiti C, Dib C, Leclère FM, Valenti P. Results of 45 arthroscopic Bankart procedures: Does the ISIS remain a reliable prognostic assessment after 5 years? Eur J Orthop Surg Traumatol 2015;25: 709-716.

78. Kim SJ, Kim SH, Park BK, Chun YM. Arthroscopic stabilization for recurrent shoulder instability with 
moderate glenoid bone defect in patients with moderate to low functional demand. Arthroscopy 2014;30:921-927.

79. Ng DZ, Kumar VP. Arthroscopic bankart repair using knot-tying versus knotless suture anchors: Is there a difference? Arthroscopy 2014;30:422-427.

80. Kim D-S, Yi C-H, Yoon Y-S. Arthroscopic repair for combined Bankart and superior labral anterior posterior lesions: a comparative study between primary and recurrent anterior dislocation in the shoulder. Int Orthop 2011;35:1187-1195.

81. GWW Ee, Mohamed S, Tan AHC. Long term results of arthroscopic Bankart repair for traumatic anterior shoulder instability. J Orthop Surg Res $2011 ; 6: 28$.

82. Zhu Y-M, Lu Y, Zhang J, Shen J-W, Jiang C-Y. Arthroscopic Bankart repair combined with remplissage technique for the treatment of anterior shoulder instability with engaging Hill-Sachs lesion: a report of 49 cases with a minimum 2-year follow-up. Am J Sport Med 2011;39:1640-1647.

83. Mohtadi NGH, Chan DS, Hollinshead RM, et al. A randomized clinical trial comparing open and arthroscopic stabilization for recurrent traumatic anterior shoulder instability: two-year follow-up with diseasespecific quality-of-life outcomes. J Bone Joint Surg Am 2014;96:353-360.

84. Elmlund A, Kartus C, Sernert N, Hultenheim I, Ejerhed L. A long-term clinical follow-up study after arthroscopic intra-articular Bankart repair using absorbable tacks. Knee Surg Sport Traumatol Arthrosc 2008; 16:707-712.

85. Carreira DS, Mazzocca AD, Oryhon J, Brown FM, Hayden JK, Romeo AA. A prospective outcome evaluation of arthroscopic Bankart repairs: minimum 2-year follow-up. Am J Sports Med 2006;34:771-777.

86. Sommaire C, Penz C, Clavert P, Klouche S, Hardy P, Kempf JF. Recurrence after arthroscopic Bankart repair: Is quantitative radiological analysis of bone loss of any predictive value? Orthop Traumatol Surg Res 2012;98: 514-519.

87. Kemp KAR, Sheps DM, Beaupre LA, Styles-Tripp F, Luciak-Corea C, Balyk R. An evaluation of the responsiveness and discriminant validity of shoulder questionnaires among patients receiving surgical correction of shoulder instability. ScientificWorldJournal 2012;2012:410125.

88. Ahmed I, Ashton F, Robinson CM. Arthroscopic Bankart repair and capsular shift for recurrent anterior shoulder instability: functional outcomes and identification of risk factors for recurrence. J Bone Joint Surg Am 2012;94: 1308-1315.

89. Mohtadi NG, Kirkley A, Hollinshead RM, et al. Electrothermal arthroscopic capsulorrhaphy: old technology, new evidence. A multicenter randomized clinical trial. J Shoulder Elbow Surg 2014;23:1171-1180.

90. Shin JJ, Mascarenhas R, Patel AV, et al. Clinical outcomes following revision anterior shoulder arthroscopic capsulolabral stabilization. Arch Orthop Trauma Surg 2015;135:1553-1559.
91. Gasparini G, De Benedetto M, Cundari A, et al. Predictors of functional outcomes and recurrent shoulder instability after arthroscopic anterior stabilization. Knee Surg Sports Traumatol Arthrosc 2016;24:406-413.

92. Robinson CM, Jenkins PJ, White TO, Ker A, Will E. Primary arthroscopic stabilization for a first-time anterior dislocation of the shoulder. A randomized, double-blind trial. J Bone Joint Surg Am 2008;90:708-721.

93. Hantes ME, Venouziou AI, Liantsis AK, Dailiana ZH, Malizos KN. Arthroscopic repair for chronic anterior shoulder instability: a comparative study between patients with Bankart lesions and patients with combined Bankart and superior labral anterior posterior lesions. Am J Sports Med 2009;37:1093-1098.

94. Milano G, Grasso A, Santagada DA, Saccomanno MF, Deriu L, Fabbriciani C. Comparison between metal and biodegradable suture anchors in the arthroscopic treatment of traumatic anterior shoulder instability: A prospective randomized study. Knee Surg Sport Traumatol Arthrosc 2010;18:1785-1791.

95. van der Linde JA, van Kampen DA, Terwee CB, Dijksman LM, KleinJan G, Willems WJ. Long-term results after arthroscopic shoulder stabilization using suture anchors: an 8- to 10-year follow-up. Am J Sports Med $2011 ; 39: 2396-2403$.

96. McRae S, Leiter J, Subramanian K, Litchfield R, MacDonald P. Randomized controlled trial of arthroscopic electrothermal capsulorrhaphy with Bankart repair and isolated arthroscopic Bankart repair. Knee Surg Sport Traumatol Arthrosc 2015;24:414-421.

97. Kim SH, Ha KI, Jung MW, Lim MS, Kim YM, Park JH. Accelerated rehabilitation after arthroscopic Bankart repair for selected cases: a prospective randomized clinical study. Arthroscopy 2003;19:722-731.

98. Cole BJ, L'Insalata J, Irrgang J, Warner JJ. Comparison of arthroscopic and open anterior shoulder stabilization. A two to six-year follow-up study. J Bone Joint Surg Am 2000;82-A(8):1108-1114.

99. Salomonsson B, Abbaszadegan H, Revay S, Lillkrona U. The Bankart repair versus the Putti-Platt procedure: a randomized study with WOSI score at 10-year follow-up in 62 patients. Acta Orthop 2009;80:351-356.

100. Lädermann A, Tirefort J, Zanchi D, et al. Shoulder apprehension: a multifactorial approach. EFORT Open Rev 2018;3:550-557.

101. Kasik C, Saper MG. Variability of outcome reporting following arthroscopic Bankart repair in adolescent athletes: a systematic review. Arthroscopy 2018;34: 1288-1294.

102. Gigis I, Heikenfeld R, Kapinas A, Listringhaus R, Godolias G. Arthroscopic versus conservative treatment of first anterior dislocation of the shoulder in adolescents. J Pediatr Orthop 2014;34:421-425.

103. Shymon SJ, Roocroft J, Edmonds EW. Traumatic anterior instability of the pediatric shoulder: a comparison of arthroscopic and open bankart repairs. J Pediatr Orthop 2015;35:1-6. 


\section{Appendix 1. Search terms}

\section{PubMed search:}

((((Shoulder[Mesh] OR Shoulder Joint[Mesh] OR shoulder*[tiab] OR glenohumeral[tiab]) AND (Joint Dislocations[Mesh] OR dislocation*[tiab] OR *luxat* [tiab] OR joint instability[Mesh] OR instability[tiab])) OR shoulder dislocation[Mesh]) AND (Recurrence [Mesh] OR recurren*[tiab] OR relaps*[tiab] OR redislocat*[tiab] OR reluxat*[tiab] OR resubluxat*))

\section{EMBASE search:}

(((shoulder* OR glenohumeral) AND (dislocation* OR *luxat* OR instability)) AND (recurren* OR relaps* OR redislocat* OR reluxat* OR resubluxat*)) 